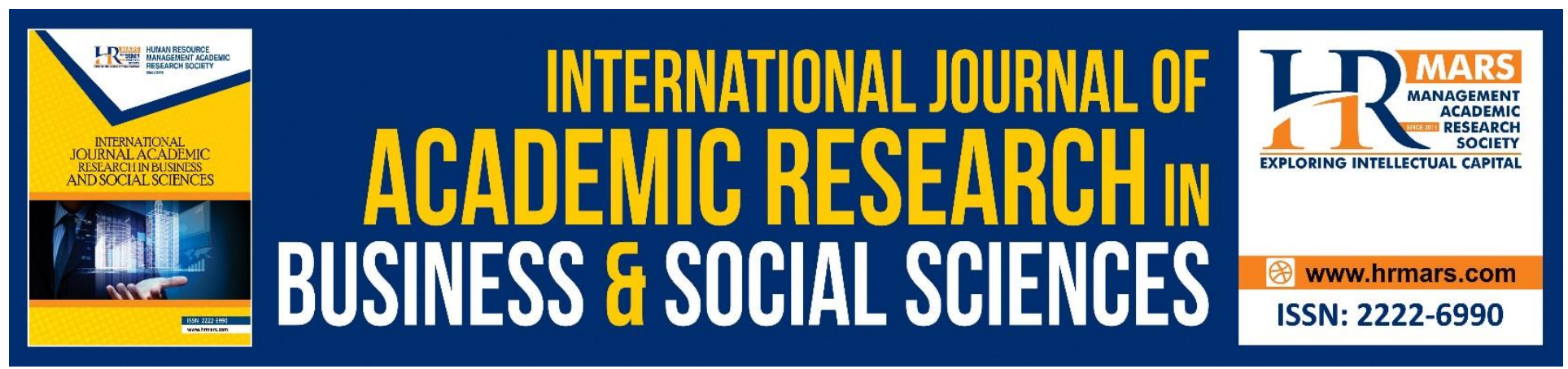

\title{
Poverty: A Literature Review of the Concept, Measurements, Causes and the Way Forward
}

\section{Rusitha Wijekoon, Mohamad Fazli Sabri \& Laily Paim}

To Link this Article: http://dx.doi.org/10.6007/IJARBSS/v11-i15/10637

DOI:10.6007/IJARBSS/v11-i15/10637

Received: 09 May 2021, Revised: 30 May 2021, Accepted: 20 June 2021

Published Online: 22 July 2021

In-Text Citation: (Wijekoon et al., 2021)

To Cite this Article: Wijekoon, R., Sabri, M. F., \& Paim, L. (2021). Poverty: A Literature Review of the Concept, Measurements, Causes and the Way Forward. International Journal of Academic Research in Business and Social Sciences, 11(15), 93-111.

Copyright: (C) 2021 The Author(s)

Published by Human Resource Management Academic Research Society (www.hrmars.com)

This article is published under the Creative Commons Attribution (CC BY 4.0) license. Anyone may reproduce, distribute, translate and create derivative works of this article (for both commercial and non-commercial purposes), subject to full attribution to the original publication and authors. The full terms of this license may be seen at: http://creativecommons.org/licences/by/4.0/legalcode

Special Issue: Empowering Youth and Community Wellbeing for Sustainable Development, 2021, Pg. 93 - 111 http://hrmars.com/index.php/pages/detail/IJARBSS

Full Terms \& Conditions of access and use can be found at http://hrmars.com/index.php/pages/detail/publication-ethics 


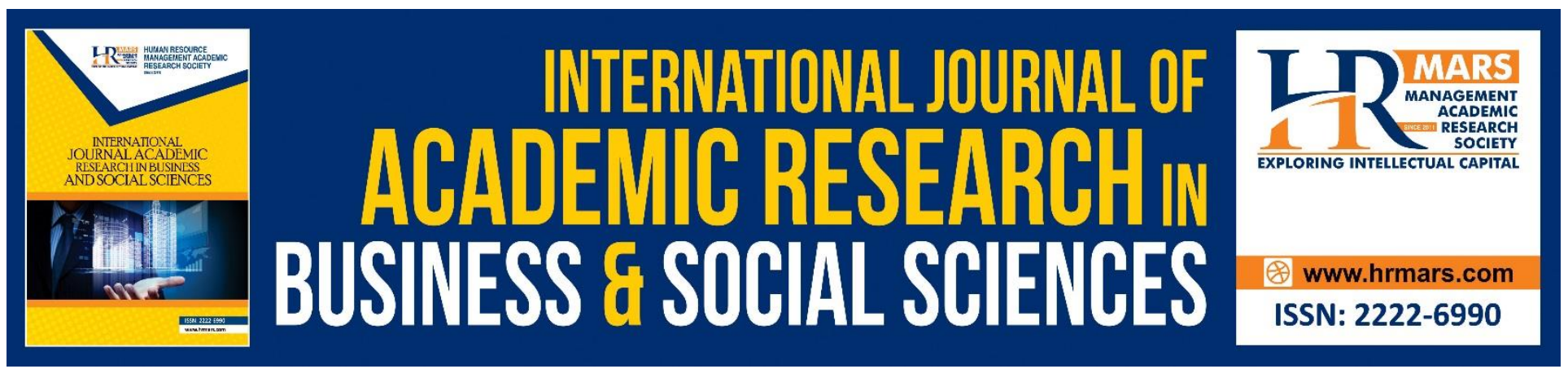

\title{
Poverty: A Literature Review of the Concept, Measurements, Causes and the Way Forward
}

\author{
${ }^{2,3}$ Rusitha Wijekoon, 1,2Mohamad Fazli Sabri \& ${ }^{2}$ Laily Paim
}

${ }^{1}$ Institute for Social Science Studies, Universiti Putra Malaysia, 43400 UPM Serdang, Selangor, Malaysia, ${ }^{2}$ Department of Resource Management \& Consumer Studies, Faculty of Human Ecology, Universiti Putra Malaysia, 43400 UPM Serdang, Selangor, ${ }^{3}$ Technology Transfer Division, Coconut Research Institute of Sri Lanka, Lunuwila, 61150, Sri Lanka.

Email: fazli@upm.edu.my

\begin{abstract}
In spite of the fact that there is some lucidity within the field of poverty with respect to the concept, measurements, causes, and the way forward, those exterior to the field are confronted with an apparently complex poverty literature, overlapping terminology, and several published measures. Therefore, the objective of this review was to give an overview of concepts, measurements, causes and the way forward on poverty. A systematic literature review was performed by searching websites, and electronic databases from January 2000 to September 2020, and the selected articles were then analyzed thematically. Twenty research articles, and 23 website articles were incorporated in the analysis. In the current paper authors try to develop a guidance to the academicians and policy makers who are looking to use poverty in their work. Further, it gives an outline of the various conceptualizations of poverty, and afterward give a set of recommendations for researchers, and practitioners with respect to the most appropriate measures of poverty for a scope of various purposes, and policy implications for the way forward the poverty.
\end{abstract}

Keywords: Absolute Poverty, Global Poverty, Poverty Alleviation, Poverty Line, Poverty Measures

\section{Introduction}

Nowadays, the entire world is making enormous steps in overwhelming worldwide poverty. Earlier more than $20 \%$ of the population in the world is under the extreme poverty, and it is a huge issue for the whole world, since a large number of individuals die every year because of this big issue. Further, it hinders the economic growth of a nation that a segment of the people has been financially vulnerable. It has become a social, political, and economic issue all over the world especially in the developing and third-world nations, and has been influencing on individuals, who are living with the minimum level of standards. But, currently less than $10 \%$ of the global population live in extreme poverty who are surviving on $\$ 1.90$ a day or less (World Vision, 2018a). Hence, living in poverty implies a daily existence of deprivation, and struggle. Therefore, the poverty is a big issue that wants to be required to address by everyone in the world, because it is getting worst as time goes on. 
Furthermore, different definitions create complications for the comprehension of issues related to the poverty, and finding the most ideal answer. Therefore, both the practical and theoretical phases of poverty abolition correlated actions appear to be unfeasible, and theoretically unreliable in many circumstances. Therefore, this review gives an overview of principle concepts of poverty to make sure people understand what poverty is, different approaches to measuring it, the major and minor causes of poverty and the way forward it at the global level.

A universally accepted, and concise meaning of poverty is elusive to a great extent, since it influences numerous features of the people's circumstances, such as, physical, psychological, and moral. Therefore, various measures could be utilized for conceptualization of the poverty. Majority of the investigations utilize the conventional perspective of poverty due to the inadequate earnings to buy basic goods and services. Some other experts define poverty as a function of health, education, life expectancy, child mortality etc. According to the findings of Blackwood and Lynch (1994), the poor can be distinguished utilizing some criteria, such as the degrees of expenditure, and consumption. Moreover, Sen (1983) described poverty as "entitlements which are taken to be the various bundles of goods and services over which one has command, taking into cognizance the means by which such goods are acquired and the availability of the needed goods" (p. 157).

However, others comprehend poverty in very expansive terms, for example, being not able to address essential requirements for a quality life; "physical; food, shelter, education, health care", etc., and "non - physical; identity, participation", etc. (World Bank, 2016). Poverty may emerge due to the variations in the distribution of income or variations in average income. If the average incomes are above the poverty line, the poverty will be less, but the other factors, such as the distribution of income should be equal. When comparing two nations with equal poverty line, and mean incomes, but one country has a broader income distribution or the country with high income inequality, for instance, generally poverty might be higher in the country having greater inequality, meanwhile, there might be comparatively greater amount of individuals having incomes below the poverty line. Therefore, the income distribution plays a vital role in influencing the poverty.

The literature in the context of Social Science is abundant with endeavours by social scientists, and economists to conceptualize the poverty. Generally, conceptualization of poverty could be done in four different ways; "these are lack of access to basic needs/goods; a result of lack of or impaired access to productive resources; outcome of inefficient use of common resources; and result of exclusive mechanisms" (Olowa, 2012, p. 29). Poverty that is due to the absence of the access to the elementary goods/services is basically economic or consumption focused. It clarifies poverty in material terms, and explicitly utilizes consumption-based classifications to clarify the degree and profundity of poverty, and set up whether who is poor, or not poor. Hence, the poor are imagined as the people or families in a specific society who cannot afford a listed package of basic goods and services.

Basic goods can be defined as "nutrition, shelter/housing, water, healthcare, access to productive resources including education, working skills and tools and political and civil rights to participate in decisions concerning socio-economic conditions" (Streeten and Burki, 1978, p. 415). The initial four requirements are the fundamental necessities for living. Impeded admittance to the productive resources, for example, financial assets, agricultural land, and physical capital; directs to 
unemployment, undernourishment, absolute low income, etc. Insufficient endowment of human capital is additionally a significant reason for the poverty. Normally, impeded admittance to the resources changes the attention on poverty, and it diminishes the capacity of person to change accessible beneficial assets to a better quality of life (Adeyeye, 1987; Ogwumike, 2002; Sen, 1976).

The article is structured in five sections. First, authors present the brief introduction of the statistics of the global poverty, and poverty definitions. Then, we present the methodology of the systematic review. Third, we provide an analysis of the results, outlining the theoretical implications and practical contributions. Under this section majorly we discuss the poverty definitions, concepts, measurements, causes, and the way forward. All the current definitions of poverty are discussed, for example, absolute poverty approach definition, relativist poverty approach definition, and budget standards method. As well as current concepts of poverty, for instance, absolute and relative poverty, objective and subjective perspectives, physiological and sociological deprivations are also explained. Moreover, measuring the poverty is very important to know the level of poverty in different countries, and therefore, current poverty measurements, such as, headcount index, income gap ratio, poverty gap and squared poverty gap, Sen index, the Sen-Shorrocks-Thon index are given and the pros and cons of them are discussed. Furthermore, different root causes of poverty, for example, low economic growth performance, microeconomic shocks and policy failures, labour market deficiencies, migration, unemployment and underemployment, human resource development, debt burden, governance, crime and violence, and environmental degradation are explained. As the final part of the discussion how the poverty is reduced is discussed under the topic of the way forward. Fourth, we conclude the findings, and finally, discuss the limitations of the study by proposing avenues for future research.

\section{Methodology}

This literature review had four related objectives; first to identify different concepts of poverty that are used in the literature. The second aim was to identify previous studies that have explored the validity and reliability of the specific poverty measures identified, and their related pros and cons. Third, to review the major and minor causes of the poverty that are identified related to the different countries, and finally, discuss the methods that are used to reduce the global poverty.

To accomplish the expressed review objectives, a systematic literature review was done by utilizing an archival method to review the articles cited in the databases; Google Scholar, SCOPUS, and web sites; Google, Yahoo, and Google Scholar with poverty as the major topic. Therefore, this review was a desk research rather than a survey or any other mode of researching.

In this case, three significant observations were identified. First, a systematic review permits authors to choose the most significant studies to address the research question, and it reduces the risk of errors. Second, the predefined inclusion and exclusion criteria are served to recognize, select, and unfavorably evaluate existing empirical studies that are related to the review objectives. This methodology is thus associated with a structured design, and thus, duplications are allowed. Third, the rising number of research on poverty have created contradictory results about the concept, measurements, causes, and the way forward. Therefore, it is challenging to get an overall clear view on the topic poverty. 
INTERNATIONAL JOURNAL OF ACADEMIC RESEARCH IN BUSINESS AND SOCIAL SCIENCES

Vol. 11, No. 15, Empowering Youth and Community Wellbeing for Sustainable Development, 2021, E-ISSN: 2222-6990 @ 2020 HRMARS

\section{Literature Search and Selection of Articles}

The first stage involves selecting ideal keywords to search related research articles from the selected databases. As a result of this selected key words are "poverty", "global poverty", "rural poverty", "poverty definitions", "poverty concepts", "poverty measures", and "way forward of the poverty". Then, the related articles were downloaded which were published between 2000 and 2020 from the above databases, and the related websites were recorded and listed for further selection.

The second stage included characterizing of inclusion and exclusion criteria (Table 1 ) for the final article selection. Next, the articles and web sites recognized as potentially related $\left(\mathrm{n}_{1}=541\right.$ articles, and $n_{2}=10,005$ websites) were tentatively incorporated, and studied in depth. Finally, the decision to include or exclude was taken only once after reading the whole article, or website. Next step, 20 research articles, and 23 website articles were retained. All the steps undergo in the process of article selection was described earlier are given in the Figure 1.

Table 1: Inclusion and exclusion criteria

\begin{tabular}{l|l|l}
\hline \multicolumn{1}{c|}{ Characteristics } & \multicolumn{1}{c}{ Inclusion Criteria } & \multicolumn{1}{c}{ Exclusion Criteria } \\
\hline Temporal horizon & $\begin{array}{l}\text { January } 2000 \text { to September } \\
2020\end{array}$ & $\begin{array}{l}\text { All papers and websites } \\
\text { published before January } \\
2000 \text { or after September } \\
2020\end{array}$ \\
\hline $\begin{array}{l}\text { Type and design of } \\
\text { research }\end{array}$ & $\begin{array}{l}\text { Empirical (quantitative and } \\
\text { qualitative) }\end{array}$ & $\begin{array}{l}\text { Theoretical, conceptual } \\
\text { Quality criterion }\end{array}$ \\
$\begin{array}{l}\text { Indexed, peer-reviewed } \\
\text { academic journals, and } \\
\text { reputed websites }\end{array}$ & $\begin{array}{l}\text { Books, conference papers } \\
\text { and professional journals }\end{array}$ \\
\hline Language of publication & English & $\begin{array}{l}\text { All other languages except } \\
\text { English }\end{array}$ \\
\hline
\end{tabular}

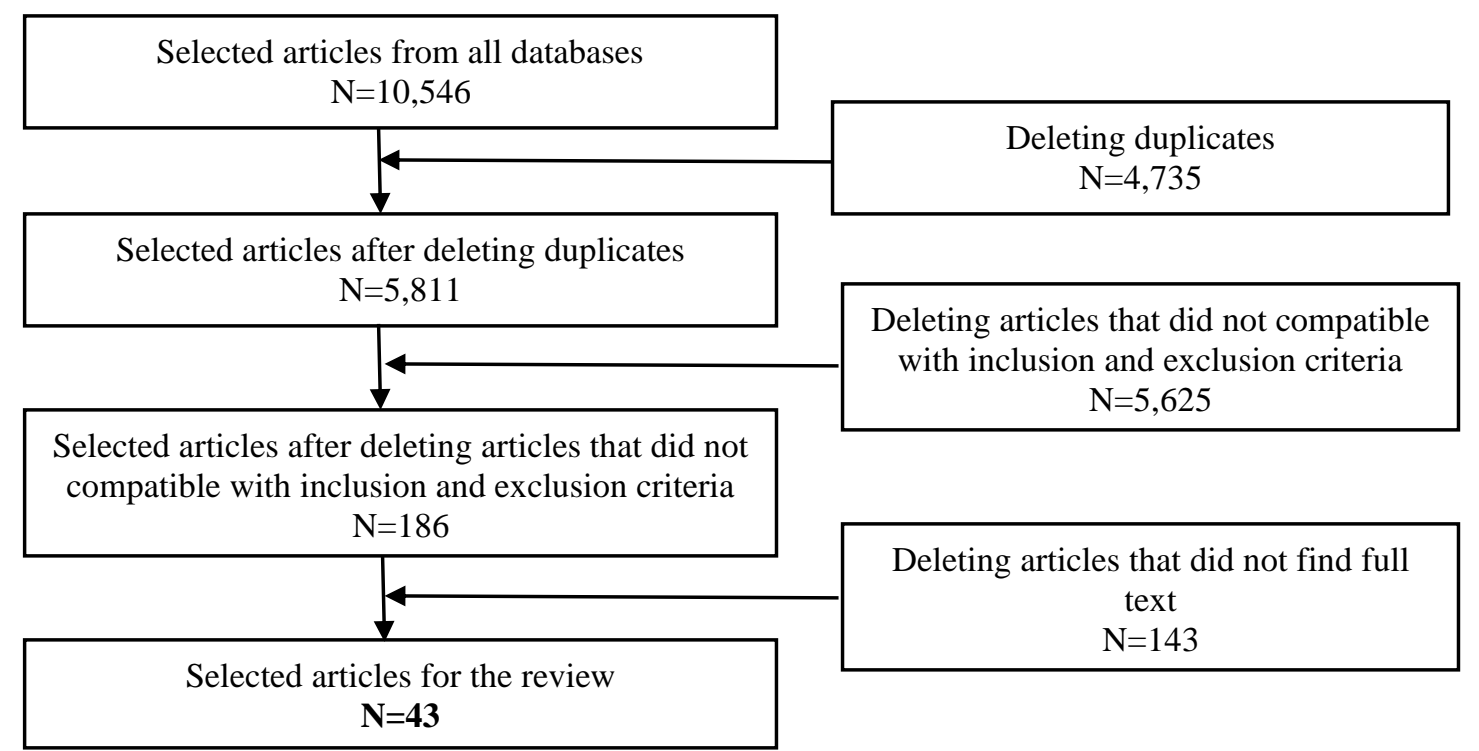

Figure1: Flow diagram for selection of the articles 


\section{Results and Discussion}

Forty-three articles were selected to extract the details of poverty concept, measurements, causes and the way forward, and discussed below.

\section{Definitions of Poverty}

According to the existing literature, various kinds or classes of poverty definitions and indicators are available. Due to the multidimensional nature of the poverty, it is defined and estimated in a huge number of ways. Further, the unpredictability nature of the problem, the multifaceted idea of the phenomenon and the related various concepts are the best way to give introduction to the issue of the poverty. However, both social policies, and poverty investigations utilize a varied assortment of poverty explanations, but all of them might be categorized under one of the given classifications;

- "Poverty is having less than an objectively defined, absolute minimum"

- "Poverty is having less than others in society, in relative terms"

- "Poverty is feeling you do not have enough to get along" (Panday, 2008, p. 183).

The first group of definitions is absolute, while second group is relative. The combination of both absolute and relative poverty are included in the third group. Characterizing the degree of poverty based on the various explanations under the above given classifications might bring about various evaluations of the quantity of poor individuals in the population.

\section{Absolute Poverty Approach Definition}

This approach to characterizing poverty starts with the "minimum subsistence" concept which is described as, "some bundles of goods and services that are regarded as essential to the physical need of an individual or a family" (Eskelinen, 2011, p. 1). The individuals who cannot afford these goods and services due to lack of the ample monetary assets are viewed as poor. This strategy for investigation was most frequently utilized in the first phase of this century, but the researchers nowadays seldom employ the absolutist approach, because it comprises theoretical and methodological complications, for example, the quantitative assessment of the demand for necessities, and determination of necessities.

\section{Relativist Poverty Approach Definition}

As per the relativist poverty method to describing poverty, "the mean or median value of national income represents the economic indicator which corresponds to the dominant life style. An individual or a family whose income is less than that value can be defined as being on the poverty threshold, with no means to live in that life style" (Eskelinen, 2011, p. 26). For instance, an individual or household with less than $50 \%$ of the average after-tax income could be defined as poor.

Several criticisms are associated with the relative poverty. First, it propagates poverty in the measurable sense that some fixed percentage of the population is constantly viewed as poor, and poverty thus persistently occurs. Second, a relative poverty approach could offer an approximation of the magnitude of the poor, but any data on the quality of life of the poor are not given.

\section{Budget Standards Method Definition}

This definition depends on the assurance of a list of requirements. Individuals who cannot acquire all necessities on the list could be viewed as poor. It is an absolutist methodology in structure, however different socially decided fundamental requirements are fused to shape a bunch of financial 
plans. All in all, this definition depends on the idea of a set of goods and services consisting the components of "subsistence" and "basic minimums" for social lives.

There are criticisms against this method. First, it is difficult to produce commonly satisfied criteria for choosing the necessities to be incorporated into the list. Second, the description of necessities is also depended on the societal development. Therefore, subjective value-judgments must be made in the context of each community's financial conditions to build up the constituents. Third, it needs colossal endeavours to build up a financial plan for the expenditure constituents, and to maintain each list up-to-date in accordance with altering social conditions.

According to Mat Zin (2011), the case, and generic theories of poverty are highly concerned with poverty. Based on the case theories of poverty, people who cannot uphold themselves and to manage the cost of the fundamental necessities without the help are viewed as living in poverty, for example, drug addicts, older people, handicapped people, and mentally ill persons. As indicated in the generic theories of poverty, macro-economic issues are associated with the poverty, for example, low demand, low national income, and inadequate employment opportunities.

\section{Concepts of Poverty}

Absolute and Relative Poverty

Absolute and relative terms could be used to define Poverty. Absolute poverty alludes to survival beneath least, socially adequate living circumstances, normally settled dependent on basic products, and nutritional necessities. Relative poverty looks at the most minimal sections of a populace with upper fragments, typically estimated in income quintiles or deciles. Absolute and relative poverty patterns might move in inverse ways. For instance, relative poverty might decline while absolute poverty increments, if the gap between lower and upper strata of a population is diminished by a decrease in well-being of the previous, while extra family units fall underneath the absolute poverty line.

Amartya Sen brings up that "poverty could be an absolute concept in the space of abilities, however, relative in that of characteristics or commodities" (Sen, 1994, p. 10). Moreover, both the absolute and relative poverty are related to fluctuations in conditions, and a similar circumstance emerges, when status or cultural values alter over time. To cite Paul Streeten, "Absolute deprivation is a function of relative advantage" (Streeten, 1994, p. 19).

\section{Objective and Subjective Perspectives}

Objective or subjective perspectives are alternative way to approach poverty. The objective perspective includes normative judgements as to what comprises poverty, and what is necessary to transfer individuals out of their underprivileged state. The subjective perspective puts a best on individuals' inclinations, on the amount they esteem services and goods. Economists have generally put together their effort with respect to the objective method, mainly due to the hindrances experienced when attempting to aggregate numerous individual utilities over a population. The poverty estimation has customarily been overwhelmed by the objective method. But, generally the global community recently has taken a serious enthusiasm in measuring subjective poverty. 


\section{Physiological and Sociological Deprivations}

The perceived causes of poverty are important to derive several poverty concepts and they could be separated into two forms of deprivations; physiological and sociological. With respect to previous, the line of thinking is as per the following; people could be poor due to lack of food, clothing, shelter, and income. Both the fundamental necessities, and income concepts of poverty originate from physiological deprivations. Procedures to decrease poverty rising up out of these methodologies focus on expanding the salary/utilization of poor people and their achievement of "satisfiers" of essential needs, for example, education, and health.

The concepts of poverty rising up out of the point of view of sociological deprivations are established in fundamental basic imbalances and natural hindrances. They depend on perceptions that in any event, when assets are flowing into divisions overwhelmed by poor people, the last will most likely be unable to exploit them due to basic obstructions. These imperatives hinder the access to "external" resources, for example, infrastructure, common property, and credit, and "internal" assets, for example, health, nutrition, and education by the poor. Along with this, poverty is "not merely in the impoverished state in which the person actually lives, but also in the lack of real opportunity-due to social constraints as well as personal circumstances-to lead valuable and valued lives" (UNDP, 1997, p. 16).

\section{Measurements of Poverty}

Poverty could be estimated in various manners by governments, global organizations, policy makers and practitioners. Generally, poverty is estimated by contrasting an individual's or household's minimum amount of income expected to cover fundamental needs or income to a set poverty threshold. Persons whose income is fallen under their threshold are regarded as poor (The U.S. Census Bureau, 2019).

The poverty is known as "multidimensional, involving social, natural and economic components arranged inside more extensive socio-political procedures" (Wikipedia, 2019a, p. 1). Therefore, measuring poverty without dismissing its different measurements is essential, and Adeyeye and Ajakaiye (1999), focused on poverty estimation is attempted to; decide a measure for estimating way of life, choose a cut-off poverty line that isolates the poor from the non-poor, assess the dissemination of way of life among poor people, assessment of poverty over the long haul, among people, households, or countries, and establish a guiding policy on poverty alleviation.

The desired characteristics of measuring of the poverty are;

- "Monotonicity axiom- measure of poverty should increase when the income of the poor family unit diminishes.

- The transfer axiom- poverty of family unit should increase when income is moved from a poor to a less poor family unit.

- Demonstrate the distribution of living standard among poor people

- The measure ought to be additively decomposable by populace sub groups" (Morduch, 2006, p. 20).

By measuring poverty, we can realize how much poverty occurs in our society, differentiate which groups are generally influenced by poverty and screen changes in its level and dispersion. The well- 
known strategy for estimating poverty is by a study in which a representative sample of individuals are requested to participate a survey that contains questions on their income and spending (SILC preliminary report, 2010). A person is viewed as poor if either expenditure or income falls underneath some least level that characterizes basic necessities in each society called, the poverty line. It is not equivalent everywhere because it is comparative with what is the standard in a specific nation.

The fundamental poverty line utilized in the Organization for Economic Co-operation and Development (OECD), and the European Union is a relative poverty measure dependent on "economic distance", a degree of income normally set at $60 \%$ of the median family income (Wikipedia, 2019b). A poverty threshold or a worldwide poverty line is the line underneath, which it is hard to manage the cost of essential requirements, and it is the standard poverty line for estimating the global poverty. The poverty line is resolved in every nation by including the expense of addressing least needs, for example, food and shelter. Though, comparatively new estimates, for example, the Global Multidimensional Poverty Index incorporates estimations of living standards, education, and health as poverty indications.

The poverty lines are different nations to nation, for example, the cost of living in higher income nations' is greater, and thus the poverty line is greater, as well. The World Bank (2018) declared novel middle poverty lines, and the nations are grouped into "low-income", "middle-income", and "highincome" countries, and developed the "median poverty line" for those categories:

- "\$1.91 per person per day - in 33 low-income countries

- \$3.21 per person per day - in 32 lower-middle-income countries, such as India and the Philippines

- $\quad$ \$5.48 per person per day - in 32 upper-middle-income countries, such as Brazil and South Africa

- \$21.70 per person per day - in 29 high-income countries" (World Bank, 2018)

Presently $\$ 1.90$ set as the worldwide poverty line per day, and it is considered as the universal standard for estimating worldwide poverty. It assists to quantify the quantity of individuals existing in extreme poverty, and assists with contrasting levels of poverty between nations. When the proper standard for poverty line is utilized for the estimations, the information might be deciphered via utilizing various methods for measures, for example, the "Headcount Ratio, the Income Gap Ratio, the Poverty Gap, the Squared Poverty Gap, the Sen Index, and The Sen-Shorrocks-Thon Index" (World Bank, 2016). But, not all these poverty indicators have the similar ramifications because of the way that they change regarding characteristics that they give as insight. Three noteworthy measurements, about which an ideal poverty measure might be "Three I's of poverty" which are "incidence", "intensity", and "inequality". Whereas, the incidence denotes the measure is capable to indicate the quantity of individuals beneath the poverty line, the intensity infers the seriousness of poverty, and the inequality implies whether the measure uncovers the level of inequality among poor people (Jenkins and Lambert, 1997).

\section{Headcount Index}

The headcount index or headcount ratio is "the population proportion that exists or lives below the poverty threshold" (Tendulkar and Jain, 1995, p. 1375). It is considered that the ordinarily 
prepared measure of the poverty due to its easiness to conduct, and to be compared. In the event that the headcount proportion is half, it implies that the half of the population is below the neediness line. Nevertheless, it fulfills just the focus and population axioms, and it indicates just occurrence measurement of poverty. Thus, it may be less instructive as well as deluding.

\section{Income Gap Ratio}

"The average contrast between the poverty line and the average income of poor people is called the Income Gap Ratio" (Duclos and Araar, 2006, p. 84). If the average income of the poor equivalents to the $80 \%$ of the poverty line, the income gap ratio of a population is equal to the $20 \%$. Moreover, the intensity of the poverty could be indicated by the Income gap ratio, while it lacks intuition about inequality and incidence. Further, similar headcount ratio, it meets all requirements for the concentration, and population axioms while it disrupts the transfer principles and monotonicity.

\section{Poverty Gap and Squared Poverty Gap}

The Poverty Gap is obtained by linking the income gap ratio and headcount ratio, and can demonstrate the both the rate and intensity of the poverty simultaneously. It is an important measure that fulfills monotonicity unlike income gap ratio, and headcount ratio. It does not portray the adjustments in the inequality with poor people. To quantify inequality, other than intensity and incidence among the poor people, the Squared Poverty Gap is used, which can display the consequences of move of income inside the populace of the poor that is likewise sensitive to the fluctuations in the inequality.

\section{Sen Index}

The Sen Index was introduced in 1976 by Amartya Sen as a poverty measuring index that fulfills all axioms, together with the transfer principle, by means of expansion of Gini Index of the poor people (Sen, 1976). Moreover, it might consist all three l's of the poverty. Inability to be decomposed is the major constraint which is associated with the Sen Index.

\section{The Sen-Shorrocks-Thon Index}

The Sen-Shorrocks-Thon (SST) index is one of the modified versions of the Sen index, and could be defined as "which is the product of the headcount index, the poverty gap index (applied to the poor only), and a term with the Gini coefficient of the poverty gap ratios for the whole population" (Haughton and Khandker, 2009, p. 75).

\section{Approaches to Measuring Poverty}

In the process of measuring the poverty, two fundamental questions should be addressed (Bibi, 2005, p. 5);

"How do the various concepts of poverty convert into indicators for assessing it? How does one guarantee the exact compatibility between definition, and indicators?"

Therefore, first step is to investigate the various kinds and groups of indicators available to us. In order to differentiate families of poverty indicators, two basic types of distinction that can be used are quantitative/qualitative, and ends/means. 


\section{Quantitative and Qualitative}

Sometimes most of the people are unable to differentiate the difference between quantitative and qualitative indicators, and subjective and objective approaches of poverty. In fact, both quantitative and qualitative indicators could be used to measure the objective concept of poverty, and the similar approaches can be applied to subjective methodologies. For instance, an objective method to measure the poverty might reveal that perceptions of declining educational standards are the main reason of decreasing the enrolment for schools. Similarly, a subjective method to measure the poverty might disclose that family organization is a focal trait of the poverty. The misperception arises due to the key approaches; the survey questionnaires to gain objective poverty indicators, which usually place a premium on quantitative data. On the contrary, the tools which are utilized to determine subjective approaches of poverty result in substantial quantities of qualitative data. Quantitative data could be accumulated, while qualitative data normally cannot. In contrast, qualitative data might offer a subtler image of reality than can quantitative data.

\section{Ends and Means}

The difference between "means" and "ends" is a theoretical gap with respect to monitor the poverty. The means denotes to the indicators of inputs planned to accomplish a final result, whereas the ends measure the final outcomes. For instance, the price of a basic food package is a "means" parameter, while dietary value is the "ends" type. "The fact that certain means indicators correspond to measurable ends should not be misconstrued to imply that the former are exclusively responsible for latter outcomes" (Banfield, 1959, p. 362). Poverty has been conventionally estimated utilizing "means" indicators, of which the most widely recognized in the money metric family. Availability of different kinds of "means" indicators are the major advantage of utilizing "means" approach, while the essentiality of utilizing a proxy, or set of proxies with changing degrees of relationship to person's poverty definition is the key disadvantage. Despite the fact that "ends" indicators associate more intimately with the incident being estimated, they have a tendency to change gradually over time, and not adequate to monitor the poverty for the short and medium terms. Therefore, when considering the factors, such as, strengths and weaknesses of both indicator types, the purpose of the measurement of poverty, and the data availability, the ideal practical method to measure the poverty is the combination of both "means" and "ends" indicators. (Bronfenbrenner and Lampman, 1974).

\section{Conceptual Issues in the Measurement of Poverty}

The selection of factors may influence discoveries on the synthesis just as on the extent of the population of poor, and therefore, the policy type may contrast accordingly. "The choice of poverty indicator, unit of analysis, and equivalence scales, and poverty head-count versus poverty gap" are the four significant conceptual issues which are considered in the process of measuring poverty (Liu and $\mathrm{Wu}, 1998)$.

\section{Causes of Poverty}

Instead of one determinant or cause, the poverty is caused by the combination of several complex factors, for instance, low productivity and low wages in the informal sector, inappropriate macroeconomic policies, deficiencies in the labour market resulting in limited job growth, low or negative economic growth, and a lag in human resource development. Furthermore, other features such as, deterioration in living standards, and determinants of poverty or structural causes, for 
example, environmental degradation, increase in crime and violence, retrenchment of workers, a fall in the actual value of safety nets, and changes in household organization.

Low Economic Growth Performance

Economic development of a country is compulsory for the decrease the poverty. Despite the fact that, the financial development of nations in the different areas of the world has commonly been profoundly unstable since the 1980s, all in all, development rates were completely declined in some nations or negative or low due to the different external issues, for example, instabilities in worldwide interest rates on third world nations' external debt, changes in global demand for exports, and severe alterations in numerous nations' terms of trade. Moreover, all these external shocks are most likely accountable for the rise in level of poverty in different nations worldwide.

\section{Macroeconomic Shocks and Policy Failure}

The macroeconomic disequilibrium is one of the major phenomenon that is faced by the several economies of the world, mostly due to the natural disasters, terms-of-trade shocks, and balance of payments due to expansive aggregate demand policies, and it is important to embrace significant policy transformations. Therefore, such economies are susceptible to the poverty. Furthermore, both the macro-economic shocks, and policy failures are accountable for poverty massively due to the constraints of utilizing the most prominent labour asset of the poor people. Likewise, economic policies that antagonistically influence cost and admittance to credit by the poor, and will affect the poor negatively.

\section{Labour Markets Deficiencies}

A virile labour market is essential to decreasing the income inequality and poverty. In many nations worldwide the most of poor families contribute to the labour market in several ways, and therefore, poverty is the major reason for the low labour revenues to the self-employment activities of the rural areas, low wages, underemployment, and sometimes, prolonged unemployment. These issues are influenced in various manners by deficits in labour market. The higher percentage of the labourers engage as paid workers in the private informal sector, trailed by the workers in the government sector. Due to the prevailing inadequacies in the labour market, restricted absorption capacity, and occupation development in the formal sector are the major issues that are faced by the poor.

\section{Migration}

Migration rates play an important role to reduce the poverty particularly when most of people who migrate are skilled workers. Conversely, persons who emigrate create vacancies in the labour markets. Therefore, skills are drained due to the migration. Further, it diminishes the speed of financial development, and hence, decelerates the overall job formation process.

\section{Unemployment and Underemployment}

Employment is one of the significant determinants of the poverty. Productive work is vital for an employee to earn a sufficient income, and come out from the income poverty. Whereas, normally the non-poor is affected by involuntary or transitional unemployment, the poor are confronted with issues of structural unemployment due to lack of extremely low educational qualifications or skills, medical problems, geographical isolation, and in some nations, discriminations could be taken place due to the race or some other characteristics. Moreover, underemployment happens generally in the informal sectors, and results in low earnings for a significant portion of the workforce, especially 
in countryside. Unemployment is more due to the low financial development than to the direct consequences of inadequacies in the labour trade, despite the fact that guidelines influencing the formal sector are probably going to induce additional underemployment in the informal sector.

\section{Human Resource Development}

To tolerate the decrease in poverty fluctuations in the labour market can be achieved through the continuous investment in human capital with enhancements in effectiveness. Investment in individuals could uplift the living qualities of family units by increasing opportunities, attracting capital investment, increasing earning power, and raising productivity. Moreover, giving extra educational opportunities for teenagers might avoid some adolescences from getting associated with drugs, violence, and gangs, given the proof connecting the culprits of crime after leaving the school. Furthermore, healthiness is essential to social wellbeing, and a central goal of financial and social development. Poor health holds back growth and economic development, shackles human capital, impedes entrepreneurial activities, and reduces returns to learning. Therefore, illnesses are a source of poverty, and vice versa.

\section{Debt Burden}

In some developing nations, debt burden is a significant factor that cause poverty. Those nations servicing of the debt has influenced on the capacity of assets required for socio-economic improvement. The industrious sector, for example, agriculture, manufacturing, etc. is similarly constrained leading to low capacity utilization, low productivity, low purchasing power, and under employment, thus directing the groups of individuals to abject poverty.

\section{Governance}

The pervasiveness and persistence of poverty in some nations are associated to the absence of wide contribution in governance, and decision making. This leads among others to transparency in poor accountability, resource allocation, weak programme implementation, and monitoring (Governance Today, 2021). Finally, development programmes that are associated with an inefficient poverty reduction activities are hence incapable, and wasting of resources.

\section{Environmental Degradation}

Environmental degradation is a source of accentuated poverty. Concurrently, poverty itself could be a reason for the degradation of the natural environment. This reverse interconnection stems from the fact that for poor individuals in some third world nations, for example, Nigeria, a various natural habitats are complementary in manufacturing and consumption to other goods and services, while various ecological assets supplement income most particularly in season of intense financial pressure (Falconer and Arnold, 1989; Falconer, 1990). This could be a foundation of accumulative causations, where environmental degradation, high fertility rates and poverty feed upon each other. Indeed, a disintegration of the ecological resource base could make certain classes of individuals desperate even when the economy on the average develops (Dasgupta, 1993).

\section{Crime and Violence}

A rise in crime and violence has affected badly to the quality of life to a varying magnitude in numerous regions in the world. Though, people of all socioeconomic clusters are affected by these social problems, the urban poor are the most vulnerable group. There are serious economic costs 
due to the crime and violence. For example, a growing percentage of government properties, which are already limited, is essential to maintenance the rising prison population, strengthen police enforcement, provide health care for persons injured by violence, and finance the demands place on the judicial system. However, the harmful social effects of crime are firmly connected with poverty (Hartinger-Saunders et al., 2012).

\section{Way Forward}

First of all, we have to identify the causing factors to end up the global poverty in a specific network, and thereafter sorting out what requirements to change. Since, poverty seems to be unique in different countries and is brought about by numerous factors. Hence, the process of eliminating global poverty is varying according to the context.

Access to opportunities and developing imbalances in income should be addressed immediately. Furthermore, rural and urban inequalities should be diminished and more consideration ought to be paid to expand agricultural productivity while providing expanded opportunities in non-agricultural sector too. For better economic and social opportunities, unplanned rural to urban migration is happen frequently and it is common in majority of the developing countries. Finally, the result is urban congestion and serious stress on urban facilities, for example, sanitation, water, affordable and decent accommodation.

Asset mobilization methodologies, and the utilization of assets need cautious re-evaluation, especially as outside conditions for customary types of improvement help, especially private capital flows, and official development assistance (ODA), for example, worker remittances, and foreign direct investments come to be uncertain progressively.

Financial assets should be organized to meet venture the gaps, and to finance the improvement of sustainable and comprehensive infrastructure, sanitation, health, education, urban renewal, and development of organizational capacity. Lessening poverty needs addressing a large group of domestic and external challenges. Nationwide, endeavours have to be prepared to guarantee that nations address low degrees of social protection, and growing degrees of inequality, governance, combat food insecurity, close infrastructure gaps, fortify organizations and need to pay attention to the adverse effects of climate change, ozone depletion, deforestation etc. to which nations with specific requirements are highly vulnerable.

As estimated by the Gini index, degrees of income inequality have been expanded in numerous nations with expanding per capita incomes, especially in significant economies of the region (Economic and Social Survey of Asia and the Pacific (ESSAP), 2016). There is proof to propose that other deprivations and poverty might be diminished more rapidly if inequality can likewise be decreased, or possibly held consistent (Economic and Social Council, 2017). Encouraging the "Millennium Development Goals in Asia and the Pacific" for one of the earliest endeavour by UNDP to experimentally set up whether it was conceivable to pursue a methodology that would avoid rises in inequality, concurrently decrease poverty, and boost growth.

One of the best approaches to diminish disparities and inequalities is to encourage the improvement of activities and sectors where the vulnerable and poor people work and live. Due consideration 
ought to likewise be paid to the feasible utilization of biodiversity and natural resources, while encouraging agricultural improvement, small and medium-sized enterprises, and informal sector exercises whereupon the poor significantly depend for their livelihood.

In the poverty alleviation programmes, a special policy attention is needed for the vulnerable groups such as, women, girls, the poor people and older people living in remote areas. Inappropriate application or absence of legacy rights and unclear property rights are also contributed to their marginalization. Skills development, asset formation, better access to public services, for example, non-discriminatory admission to factor markets, including basic health, microcredit, and education could increase their chances to take an interest in business sectors and upgrade their abilities to profit by the financial development process.

In addition to that, food insecurity, hunger and malnutrition are some of the important factors that should be addressed in poverty alleviation programs in nations with special requirements. The steady supply of safe and nutritious food at affordable prices and at correct places and times when they need it. A profitable agribusiness sector upheld by effective technology transfer services, transport services, rural roads, and supply chains which are functioned appropriately are vital to guarantee the food security to the poor people and the susceptible clusters.

Social protection in the types of universal access to free primary and secondary education, affordable health care, minimum wages, unemployment benefits, benefits for people with disabilities, old age pension schemes, widows' allowances, microfinance programs, cash transfers, and support for newborn babies and lactating mothers can form significant constituents in a nation's poverty decrease procedure as they keep individuals from dropping back into poverty in the consequence of external shocks. Furthermore, those actions may take a part to promote labour productivity, labour mobility, and making open doors for hazard acquiring and enhancing local demand by encouraging consumption away from the protective savings. Likewise, proofs are available to propose that nations who allocate a greater extent on social protection will generally result the lower rate of income poverty (ESSAP, 2016).

Persistent and in numerous incidents, extreme gaps in infrastructure are held back sustainable improvement and comprehensive growth in nations with distinct requirements with severe effects on poor people and on endeavors to decrease their vulnerabilities, as infrastructure assists to create a widespread range of environmental, social, and economic advantages available for the poor people, and encourages local incorporation by improved connecting investment and trade opportunities (Asia-Pacific Countries with Special Needs Development Report, 2017). Infrastructure development is required with the aim of convey services to individuals, associate markets, and exploit economic and social opportunities.

Improvement of the roads, railways, bridges, and waterways are significant for moving individuals, production inputs, and raw materials, finished products marketing and providing services. Energy, such as natural gas, and electricity is fundamental to operate rural enterprises and continue processing plants. Communication and information technologies increase the productivity and make novel financial opportunities. Health, education, and hygienic facilities are significant to enhance comprehensive growth and development, especially in enabling vulnerable groups and poor people. 
In every one of these areas, majority of nations with unique requirements face significant infrastructure discrepancies, regularly complexes further by the absence of speculation and talented human resources as well as organizational weaknesses.

The sustainability of the poverty-reduction process is completely depended on the optimistic path that we use, because it is not required to meet the poverty-reduction target just to fall back in successive years. On an empowering note, studies have proposed that lower initial degrees of absolute poverty at a given mean utilization cultivate higher resulting paces of development in average living standards in developing nations, and help to guarantee that economic development itself is poverty reducing (Ravallion, 2012). Hence, a "virtuous cycle" could be foreseen that might help to guarantee the sustainability of the poverty decreasing process.

In summary, since 1950, World Vision has been attempting to avoid the root causes of poverty, and identified biggest challenges to be overcome in the process of eliminating of global poverty such as, education, clean water, health, hunger and food security, gender equality, economic empowerment, spiritual poverty, child protection, disability inclusion, and disaster relief (World Vision, 2018b).

Furthermore, this is the only study that review the concept of poverty for the period of 2000-2020, and the current review has identified several concepts, measurements, causes, and suggests potential suggestions to reduce or eliminate the poverty. Moreover, it gives a complete assessment of existing literature as it depends on the results of numerous research carried out earlier, and related web pages. The distinguishing of different variables in this article was carried out based on the outcomes of various studies performed in different cultures and contexts, and the suitability of these facts can be empirically studied in future studies, and can be used in their poverty alleviation programmes.

There are significant managerial implications in the current review. It notifies research personals, economists, and policy makers about the overview of principle concepts of poverty to make sure people understand what poverty is, different approaches to measuring it, the major and minor causes of poverty and the way forward it at the global level. Further, valuable implications for public policies were introduced through the current review as well, and the pedagogists and policy makers should additionally nurture and build up this trend via awareness programmes.

\section{Conclusion}

If any individual country suffers with extreme poverty, it has developed in to a significant issue, a risk to the survival, stability, and improvement of the humankind and world. Nowadays, globalization can play a significant role to make a bridge for connecting nations thus, any nations' instability can legitimately and profoundly influence the steadiness of other nations. The global network has to hold hands to alleviate poverty with numerous governmental and non-governmental anti-poverty organizations that operate both regionally and internationally, including United Nations Development Programme (UNDP), World Health Organization (WHO), United Nations Programme on Reducing Emissions from Deforestation and Forest Degradation (UN-REDD), Food and Agriculture Organization (FAO), and Biosciences eastern and central Africa (BecA). The UNDP set eight Millennium Development Goals which contain major recommendations for addressing problems associate with poverty comprehensively (UNDP, 2017); 
- "Eradicate extreme poverty and hunger

- Achieve universal primary education

- Promote gender equality and empower women

- Reduce child mortality

- Improve maternal health

- Combat AIDS, Malaria and other diseases

- Ensure environmental sustainability

- Develop a global partnership for development"

Though, all of the above referenced recommendations performed straightforwardly by organizations, and nations not only emphasis on the roots of poverty, but also break its cycle. Moreover, the poor ought to have a feeling of their poverty, and must be accountable for their own destiny and effectively battle poverty as opposed to sitting tight for help.

It is obligatory a significant alteration from their very own praxis which could enable them to experience a procedure of solving problems, sharing, learning, and prompting to social developments. The individuals and the government of any nation have to understand better than any other individual clearly the characteristics and strengths of their countries. It pursues that they could productively contribute to avoid causes of poverty, solving consequences of the poverty, and preventing the return of poverty in their nations by numerous ways, for example, particularly through the proper education, awareness programmes.

In conclusion, the war against poverty is not simple to end and take time, money, human resources and energy. Once more, poor people and vulnerable groups ought to be educated to be completely mindful of their circumstance to that they can beat poverty themselves. At the point when entire world should grab hands in solving this global issue and then, the unending circle of poverty would be terminated certainly in near future. But, every nation ought to be liable for finding fitting approaches to beat poverty before getting supports from different nations.

\section{Limitations and Future Research}

In the current review, the authors attempted to be very systematic and accurate in choosing studies, for example here we selected only the empirical research articles, and web pages related to the poverty that have been published in the period of 2000-2020, and those shortcomings might be overwhelmed by future studies. The factors recognized might have different influences on individuals from different cultural and social backgrounds.

\section{References}

Adeyeye, V. A. (1987). Rural crisis in Nigeria: Increase in food deficits, decline in real income and widespread rural poverty, In NISER Seminar Series, January $28^{\text {th }}$.

Adeyeye, V. A., \& Ajakaiye, D. O. (1999). Concept, measurement and causes of poverty.

Asia-Pacific Countries with Special Needs Development Report. (2017) Structural transformation and its role in reducing poverty. Accessed on $4^{\text {th }}$ September 2020 from https: //www. unescap. org/publication-series/asia-pacific-countries-with-special-needs-development-report.

Banfield, E. C. (1959). Ends and means in planning. International Social Science Journal, 11(3), 361368. 
Bibi, S. (2005). Measuring poverty in a multidimensional perspective: A review of literature. PMMA working paper, 1-38, Accessed on $4^{\text {th }}$ September 2020 from https://www.gtap.agecon.purdue. edu/resources/download/2798.pdf.

Blackwood, D. L., \& Lynch, R. G. (1994). The measurement of inequality and poverty: A policy maker's guide to the literature. World development, 22(4), 567-578.

Bronfenbrenner, M., \& Lampman, R. J. (1974). Ends and Means of Reducing Income Poverty. The Journal of Human Resources, 9(2), 290-293.

Dasgupta, P. (1993). An inquiry into well-being and destitution. Oxford, UK: Clarendon Press.

Duclos, J. Y., \& Araar, A. (2006). Measuring Poverty. In: Poverty and Equity. Economic Studies in Inequality, Social Exclusion and Well-Being, vol. 2. Springer, Boston, MA.

Economic and Social Council. (2017). Prospects for poverty reduction in Asia and the Pacific: progress, opportunities and challenges, especially in countries with special needs. Accessed on $14^{\text {th }}$ September 2020 from https://www.unescap.org/sites/default/files/E-ESCAP-CMPF1-2-E.pdf.

Economic and Social Survey of Asia and the Pacific (ESSAP). (2016). Nurturing productivity for inclusive growth and sustainable development. Accessed on $4^{\text {th }}$ September 2020 from https://www.unescap.org/ sites/default/ files/ Economic\% 20and\%20Social\%20Survey\%20of \%20Asia\%20and \%20 the \%20Pacific\%202016_0.pdf.

Eskelinen, T. (2011). Absolute Poverty. In: Chatterjee D.K. (eds). Encyclopedia of Global Justice. Springer, Dordrecht. https://doi.org/10.1007/978-1-4020-9160-5_178.

Falconer, J. (1990). The major significance of "minor" forest products: The local use and value of forests in the West African Humid Forest Zone. Community Forestry Note 6, FAO, Rome.

Falconer, J., \& Arnold, J. E. M. (1989). Household food security and forestry: An analysis of socioeconomic issues. Community Forestry Note 1, FAO, Rome.

Governance Today. (2021). Accessed on 14 ${ }^{\text {th }}$ January 2021 from https://www.governancetoday.com/ GT/Material/Governance_what_is_it_and_why_is_it_important_.aspx\#: :text=Governance \%20can\%20be\%20defined\%20as,the\%20top\%20of\%20an\%20entity.

Hartinger-Saunders, R. M., Rine, C. M., Nochajski, T., \& Wieczorek, W. (2012). Neighborhood crime and perception of safety as predictors of victimization and offending among youth: A call for macro-level prevention and intervention models. Children and Youth Services Review, 34(9), 1966-1973.

Haughton, J., \& Khandker, S. R. (2009). Handbook on poverty+ inequality. World Bank Publications.

Jenkins, S. P., \& Lambert, P. J. (1997). Three 'I's of poverty curves, with an analysis of UK poverty trends. Oxford economic papers, 49(3), 317-327.

Liu, E., \& Wu, J. (1998). The Measurement of Poverty. Research and Library Services Division, $5^{\text {th }}$ Floor, Citibank Tower, 3 Garden Road, Central, Hong Kong.

Mat Zin, R. (2011). Poverty and income distribution in Rajah Rasiah. Malaysian economy: Unfolding growth and social change (pp. 213-224). Oxford University Press.

Morduch, J. (2006). Concepts of poverty. Handbook on poverty statistics: Concepts, methods and policy use, pp.23-50.

Ogwumike, F. O. (2002). An appraisal of poverty reduction strategies in Nigeria. CBN Economic and Financial Review, 39(4), 1-17.

Olowa, O. W. (2012). Concept, measurement and causes of poverty: Nigeria in perspective. American Journal of Economics, 2(1), 25-36.

Panday, P. K. (2008). The extent of adequacies of poverty alleviation strategies: Hong Kong and China Perspectives. Journal of Comparative Social Welfare, 24(2), 179-189. 
INTERNATIONAL JOURNAL OF ACADEMIC RESEARCH IN BUSINESS AND SOCIAL SCIENCES

Vol. 11, No. 15, Empowering Youth and Community Wellbeing for Sustainable Development, 2021, E-ISSN: 2222-6990 @ 2020 HRMARS

Ravallion, M. (2012). Why don't we see poverty convergence? American Economic Review, 102(1), 504-523.

Sen, A. K. (1976). Poverty: An ordinal approach to measurement. Econometrica, 44, 219-231.

Sen, A. K. (1983). Poor, relatively speaking. Oxford economic papers, 35(2), 153-169.

Sen, A. K. (1994). Poor, relatively speaking, in resources, values and development, Oxford, Basil Blackwell.

SILC (Survey on Income and Living Conditions): The preliminary report. (2010). Accessed on $14^{\text {th }}$ September 2020 from http://www.cso.ie/en/media/ csoie/releasespublications/ documents/ silc/ 2010/.

Streeten, P., \& Burki, S. J. (1978). Basic needs: Some issues. World Development, 6(3), 411-421.

Streeten, P. (1994). Poverty concepts and measurement, in poverty monitoring: An international concern, UNICEF.

The U. S. Census Bureau. (2019). U. S. Census 2020. Accessed on $14^{\text {th }}$ September 2020 from https://www. https://2020census.gov/.

Tendulkar, S. D., \& Jain, L. R. (1995). Economic reforms and poverty. Economic and Political Weekly, 30(23), 1373-1377.

UNDP. (1997). Human Development Report, Oxford University Press, New York.

UNDP. (2017). Asia-Pacific Sustainable Development Goals Outlook.

https://www.adb.org/sites/default/files/publication/232871/asia-pacific-sdgoutlook 2017. pdf. (Accessed 6 September 2020).

Wikipedia. (2019a). Measuring poverty. Accessed on $14^{\text {th }}$ September 2020 from https://en.wikipedia.org/ wiki/Measuring_poverty.

Wikipedia. (2019b). Causes of poverty. Accessed on $14^{\text {th }}$ September 2020 from https://en.wikipedia.org/wiki/Causes_of_poverty.

World Bank. (2016). Measuring and analyzing poverty. Accessed on $14^{\text {th }}$ September 2020 from http://web. worldbank. org/WBSITE/ EXTERNAL/TOPICS/EXTPOVERTY/EXTPA/ 0, contentMDK

:22405907 menuPK:6626650 pagePK:148956 piPK:216618 theSitePK:430367, 00.html.

World Bank. (2018). Decline of global extreme poverty continues but has slowed. Accessed on $4^{\text {th }}$ September 2020 from https://www.worldbank.org/en/news/press-release/2018/09/19/ decline-of-global-extreme-poverty-continues-but-has-slowed-world-bank.

World Vision. (2018a). Global poverty: Facts, FAQs, and how to help. Accessed on $10^{\text {th }}$ September 2020 from https://www.worldvision.org/sponsorship-news-stories/global-poverty-facts.

World Vision. (2018b). 2018 Annual Review. Accessed on $4^{\text {th }}$ September 2020 from https://www.worldvision.org/wp-content/ uploads/ 2019/01/annual-report.pdf. 